logist Karl Ludwig. Basch is best known for his invention of a sphygmomanometer, by which he inaugurated the clinical measurement of the blood pressure. He also did valuable work on pulmonary œdema, cardiac dyspnœa and the innervation of the uterus. His death took place on April 25, 1905.

\section{Local Government in Roman Britain}

A Document of importance in its bearing on the organization of local government in Roman Britain has been brought to light in the course of the fifth season's excavation on the site of the Roman town of Brough, which has just closed. The investigation of this site, which is situated on the north bank of the Humber, commanding the crossing of the river by the Lincoln-York road, is being carried out by the Brough Excavation Committee under the direction of Mr. Philip Corder and the Rev. T. Romans. The present season's work has been directed to laying bare one of the four towers of rectangular form, twenty-five feet wide by ten feet deep, which were added to the front wall of fortification, possibly early in the fourth century. The most important find of the season was an inscribed slab, 2 ft. 3 in. high by, originally, about four feet long (The Times, August 27). Mr. Eric Birley reports on the inscription that it commemorates the provision of a stage at his own expense by Marcus Ulpius Ianuarius, Aidile of the village of Petuaria, in honour of the Imperial family of Antoninus Pius (A.D. 138-161) and of the spirits of the deified emperors. This inscription confirms the name Petuaria, and is one of the few known instances of the epigraphic confirmation of RomanoBritish names.

FURTHER, and more important, the inscription affords evidence of a step in the development of the unit of local governments in Britain from the tribal area, here that of the Parisii, to the self-governing canton with its seat of government at the old tribal capital, or a newly erected town. Although such tribal cantons were known from inscriptions at Caerwent and Wroxeter, this is the first mention of a tribal magistrate in Britain. Furthermore, being denominated as the Adile not of the tribal area, as in the previously known inscriptions, but of Petuaria itself, this indicates, in the interpretation of $\mathrm{Mr}$. Birley, a further stage of development in which the central town with its college of four regular magis. trates, two duovirs and two AEdiles, was gaining in importance at the expense of the tribal organization. This inscription is also the first epigraphic evidence of the practice in Britain of a magistrate conferring benefactions in return for the honour of election to office.

\section{Arctic Weather Reports}

ONLY forty-one years have passed since Nansen made his perilous and unsuccessful attempt to drift with the arctic ice from northern Siberia across the North Pole to the neighbourhood of Greenland, yet since July at least one London morning newspaper has been publishing daily a weather report from the region of the North Pole along with similar reports from New York and various Continental capitals. Such observations are not at present of great importance to weather forecasters, because the normal travel of weather systems generally tends to be circumpolar, and, moreover, the gap between the Pole and other arctic weather stations-even Spitsbergen - is a very wide one, so wide that it is impracticable to complete a system of isobars to cover the polar regions. But as a landmark in the gradual spreading of a network of observing stations over the whole world, this event is important. Owing to the drift of the ice, a permanent station at the North Pole is impracticable, but the Russian station from which the published observations have been received has apparently not drifted very far from the Pole yet. Its co-ordinates at the end of August were about lat. $87^{\circ} \mathrm{N}$., long. $2^{\circ} \mathrm{E}$. The reports include an observation of the direction of the wind, and owing to the fact that these are not made exactly at the Pole, the direction can be given in the ordinary manner. At the Pole itself, of course, all winds are from the south, and direction would presumably have to be given in terms of longitude instead of being referred to the points of the compass.

\section{Problems of Conquering Everest}

THE problem of reaching the summit of Mount Everest is discussed in a paper in the Himalayan Journal, 9, and takes the form of a memorandum prepared by the Eastern Section of the Himalayan Club, with some comments on the conclusions by Mr. E. Shipton. Two main suggestions are made in the light of past experience. The first is that expeditions have been foredoomed to failure because they have attempted to climb the north ridge too quickly. It is contended that men who have stood the strain of reaching the North Col cannot hope to do the remaining 6,300 feet in three days. The writers quote much evidence in favour of their statement, but Mr. Shipton is equally sure that above 23,000 feet a man deteriorates in muscle and energy quickly, and therefore delay at and above that height must be avoided. The second suggestion is that instead of trying in May and June when the effort is a race with the approaching monsoon, it would be better to make the attempt after the monsoon, in October or even in April. Days in October are certainly shorter than in May, but wind velocities so far as is known are slightly lower. Mr. Shipton admits that post-monsoon conditions should be studied, but prefers the pre-monsoon season. Major K. Mason points out that one obvious drawback to October is that it is a month of increasing wind, while May is a month of west winds decreasing owing to advancing monsoon currents.

\section{The British Grid System}

IN a paper on the British Grid system by Johnstone Wright, the engineer of the Central Electricity Board, presented to the Engineering Institute of Canada, at Montreal in June last, an interesting account is given of the development of the Grid system in

(Continued on p. 419) 